Hurina Olena, Doctor of Economics, Associate Professor, Professor of the Department of Finance and Accounting, V.O. Sukhomlynskyi National University of Mykolaiv, Ukraine

ORCID ID: 0000-0002-6315-6067

e-mail: gurina161277@gmail.com

Krylenko Volodymyr, Doctor of Economics, Professor, Professor of the Department of Finance and Accounting, V.O. Sukhomlynskyi National University of Mykolaiv, Ukraine

ORCID ID: 0000-0002-1980-5533

e-mail: krylenko2021@gmail.com

Novikov Ihor, Applicant of Higher Education, V.O. Sukhomlynskyi National University of Mykolaiv, Ukraine

ORCID ID: 0000-0002-8103-6851

e-mail: natkorneva2205@gmail.com

\title{
Forecasting the Main Indicators of Insurance Companies
}

\begin{abstract}
Introduction. Econometric and adaptive models make it possible to predict financial and economic indicators in the short and long term. The most common forecasting models are linear trend models, adaptive Brown, Holt, Holt-Winters, BoxJenkins, autoregressive and other models. It has been proved that the use of adaptive forecasting models becomes especially relevant in the context of constant changes in the external environment, instability of the economic and political situation.

Purpose. The purpose of this article is to substantiate the expediency of using forecasting methods when planning the development of the insurance market and to implement the procedure for forecasting the main indicators of its development using modern methods and techniques.

Results. Improving the efficiency of the insurance market is facilitated by the correct organization of its planning and the direct implementation of the planned indicators. Optimality of planning is determined by the degree to which the accuracy of the predicted level of planned indicators is achieved. The methodology and results of the forecast of insurance payments made for the near future can be taken as a basis for drawing up current and strategic plans of insurance companies.

Conclusions. It has been established that one of the barriers to the effective development of the insurance market in general and insurance companies in particular is the insufficient level of planning of their activities, especially in terms of forecasting key indicators. The procedure for forecasting the receipt of insurance payments was implemented using modern forecasting methods. The effectiveness of the Brown's adaptive model for short-term planning of insurance premiums is proved. The proposed model was tested for adequacy, on its basis, recommendations were developed for further application in the practice of insurance companies.
\end{abstract} extrapolation.

Keywords: insurance; insurance market; planning; forecasting; econometric model; adaptive model; trend

\section{УДК 336}

Гуріна О. В., доктор економічних наук, доцент, професор кафедри фінансів та обліку, Миколаївський національний університет імені В.О. Сухомлинського, м. Миколаїв, Україна

Криленко В. І., доктор економічних наук, професор, професор кафедри фінансів та обліку, Миколаївський національний університет імені В.О. Сухомлинського, м. Миколаїв, Україна

Новіков I. О., здобувач вищої освіти, Миколаївський національний університет імені В. О. Сухомлинського, м. Миколаїв, Україна

\section{Прогнозування основних показників діяльності страхових компаній}

Анотація. У процесі людської діяльності в фінансово-економічному просторі $\epsilon$ певні ризики. 3 метою їх мінімізації приймається рішення щодо диверсибікації ризику або використання механізмів страхування. Страхування - це ефективний інструмент для зменшення невизначеності однієї сторони, яку називають страхувальником, шляхом передачі особливих ризиків іншій стороні, яку називають страховиком, і яка пропонує відновлення, принаймні частково, економічних збитків, що зазнав страхувальник. Виявлено, що через низький рівень довіри населення до ринку страхування загалом та страхових компаній зокрема, через відсутність знань у галузі страхування, попит на страхові послуги в Україні є достатньо низьким.

Доведено, що в умовах мінливості зовнішнього середовища в складній соціально-економічній та політичній ситуації в країні ефективність розвитку страхового ринку залежить від оптимальної моделі його планування. Об'єктами планування можуть виступати основні статистичні показники діяльності страхових компаній: валові страхові платежі, валові страхові виплати, страхові платежі, сплачені на перестрахування, загальні активи страхових компаній, власний капітал, грошові кошти, обсяги сформованих страхових резервів, довгострокові фінансові

Стаття надійшла до редакції: 06.01.2021

Received: 06 January 2021 
інвестиції, поточні фінансові інвестиції тощо. Обгрунтовано, що правильна організація планування та виконання планів забезпечують досягнення страховими компаніями цілей і задач розвитку. Результативність панування досягається за рахунок точності прогнозного рівня планованих показників.

У статті досліджено окремі аспекти прогнозування основних показників діяльності страхових компаній. Розкрито сутьність методів та прийомів прогнозування і визначено їх роль у діяльності страхових компаній. Методологічної основою дослідження обрано економетричні методи та методи екстраполяції тенденцій. $B$ якості прийомів прогнозування використано економетричні лінійні моделі та базові адаптивні моделі. Визначено переваги застосування у практичній діяльності розглянутих методів прогнозування. Запропоновані моделі протестовані на адекватність та зроблені висновки щодо можливості їх застосування у практиці планування обсягів надходжень страхових платежів страхових компаній України.

Ключові слова: страхування; страховий ринок; планування; прогнозування; економетрична модель; адаптивна модель; екстраполяція тенденцій.

Formulation of the problem. The insurance market has a significant impact on the sustainable development of the economy in general and its regions in particular. Acting as an important element of the country's financial system, it is the basis for redistribution and risk reduction. One of the barriers to the effective development of the insurance market is the insufficient level of its planning. The objects of planning the development of the insurance market can be the main statistical indicators: gross insurance payments, gross insurance payments, insurance payments paid for reinsurance, total assets of insurance companies, equity, cash, the volume of insurance reserves, long-term financial investments, current financial investments, etc. The effectiveness of planning is determined by the degree of accuracy of the predicted indicators and their comparability with actual data.

Analysis of recent research and publications. A large number of scientific works of domestic and foreign researchers are devoted to forecasting the performance of the insurance market. Much attention is paid to the practical application of forecasting models in the works of such authors as O. Amosha, N. Bagrov, S. Bozhko, V. Burkinsky, I. Vakhovych, V. Geets, B. Danilishin, Y. Ershov, V. Leontiev, E. Libanova, A. Loch, K. Lewis, A. Melnik, D. Morell, A. Wrights, T. Saati, B. Spencer, G. Tale, D. Winchirs, V. Shevchuk, N. Shabranska, B. Shchukin, E. Janch.

A significant number of leading scientists focused on key issues and general trends in the development of the insurance market, including forecasting its indicators, both in Ukraine and abroad, in particular O. Abakumenko, V. Bazylevych, V. Berg, A. Wagner, N. Vnukova, T. Govorushko, Y. Gorodnichenko, O. Gvozdenko, A. Duka, Y. Zhuravlyov, O. Zolotareva, M. Mnykh, R. Pikus, E. Prokopchuk, G. Puriy, Y. Romanovska, M Rothschild, P. Samuelson, L. Sarana, T. Saricheva, O. Sukach, V. Turko, V. Fedorenko, V. Furman, V. Shakhov, A. Sholoyko and many others.

Noting the unconditional advantages of the approaches proposed by the authors for planning the activities of the insurance market, it should be noted that further attention needs aspects aimed at forecasting the main indicators of its development.

Formulation of research goals. The purpose of the article is to substantiate the feasibility of using forecasting methods in planning the main indicators of the insurance market and the implementation of the forecasting procedure based on the use of modern tools.

Presentation of the main research material. The development of insurance is based on the understanding of the need for protection against sudden danger. Modernization of social relations and the participation of various branches of human activity in economic activity, in turn, led to the expansion of insurance coverage. Insurance is an indispensable part of the economic and financial sector. The need for insurance is due to the need to manage the risks that occur in the lives of individuals and economic activities of organizations (legal entities).

The maintenance and development of insurance relations is extremely important for the economy of any socially oriented state. Proper organization of its insurance planning and forecasting contributes to the effective development of the insurance market. Planning as an operational process involves the sequential implementation of three stages: analysis of the current state, forecasting future values of targets and direct planning with mechanisms for their implementation and current adjustment [5].

Forecasting the main indicators of the development of the insurance market and insurance activities of companies aims to solve the following tasks:

- determination of an objective, reasonable future state of development taking into account the available resources

- determination of the volume of key indicators to ensure long-term development;

- determining the size of extreme resource needs (equity, cash) by establishing the smallest and largest of their value;

- identification of sources of resources (equity, cash) to ensure effective development;

- determination, taking into account forecast estimates, areas of resource use to meet development needs;

- identification of factors that affect the studied processes of the future.

One of the possible ways to solve the problem is, in our opinion, the use of statistical forecasting methods that allow obtaining the expected values of the characteristics of the studied indicators.

According to the available data on the volume of insurance payments during 2010-2019 (table 1), based on linear trend models and extrapolation methods, we will build a forecast for three years. 
Електронне наукове фахове видання з економічних наук "Modern Economics", №25 (2021), 52-57 https://modecon.mnau.edu.ua | ISSN 2521-6392

Table 1 Volumes of insurance payments (contributions, premiums) in 2010-2019, UAH mln

\begin{tabular}{|c|c|c|c|}
\hline Years & $\begin{array}{c}\text { Volumes of insurance payments } \\
\text { (contributions, premiums), UAH } \\
\text { mln }\end{array}$ & Years & $\begin{array}{c}\text { Volumes of insurance payments } \\
\text { (contributions, premiums), UAH } \\
\text { mln }\end{array}$ \\
\hline 2010 & 23081,7 & 2015 & 29736,0 \\
\hline 2011 & 22693,5 & 2016 & 35170,3 \\
\hline 2012 & 21508,2 & 2017 & 43431,8 \\
\hline 2013 & 28661,8 & 2018 & 49367,5 \\
\hline 2014 & 26767,3 & 2019 & 53001,2 \\
\hline
\end{tabular}

Source: compiled by the authors for $[2,6,7]$

Using the application software - analysis package linear trend model, the results of the analysis are "Data Analysis" we performed a regression analysis of the summarized in Table 2.

Table 2 Assessment of the adequacy of the linear trend model

\begin{tabular}{|l|c|}
\hline \multicolumn{1}{|c|}{ Regression statistics } & Mean \\
\hline Multiple correlation coefficient & 0,87 \\
\hline Multiple coefficient of determination & 0,76 \\
\hline F-criterion & 24,84 \\
\hline Standard error & 6153,37 \\
\hline Number of observations & 10 \\
\hline
\end{tabular}

The results of the calculations given in the table allow us to draw conclusions about the adequacy of the constructed model. According to the Chaddock scale, there is a close relationship between the factors (multiple correlation coefficient is 0,87 ). The coefficient of determination shows that the variation in the volume of insurance payments by $76 \%$ is determined by the time factor, which also determines the accuracy of the regression (compliance of the obtained regression equation with empirical data). The influence of factors not taken into account in the model is $24 \%$.
The linear trend model of the volume of insurance payments is as follows: $Y=13738,41+\phi 3376,53 \cdot t$. The parameter $a_{0}=13738,41$ characterizes the zero level of the time series, the parameter $a_{1}=3376,53$ indicates an increase in the amount of insurance payments over time. In particular, the obtained equation determines the annual growth of the studied indicator at the level of UAH 3376,53 million.

Based on the results obtained on the basis of the linear trend model, we determine the forecast values of the studied indicator for the next three years (Table 3).

Table 3 Determination of theoretical and forecast values of insurance payments based on the model of the linear trend

\begin{tabular}{|c|c|c|c|}
\hline Year & $\begin{array}{c}\text { Volumes of insurance payments } \\
\text { (contributions, premiums), UAH mln }\end{array}$ & $t$ & $\begin{array}{c}\text { Theoretical mean of a number of } \\
\text { dynamics } Y=13738,41+3376,53 \cdot t\end{array}$ \\
\hline 2010 & 23081,7 & 1 & 17114,94 \\
\hline 2011 & 22693,5 & 2 & 20491,47 \\
\hline 2012 & 21508,2 & 3 & 23868 \\
\hline 2013 & 28661,8 & 4 & 27244,53 \\
\hline 2014 & 26767,3 & 5 & 30621,06 \\
\hline 2015 & 29736,0 & 6 & 33997,59 \\
\hline 2016 & 35170,3 & 7 & 37374,12 \\
\hline 2017 & 43431,8 & 8 & 40750,65 \\
\hline 2018 & 49367,5 & 9 & 47127,18 \\
\hline 2019 & 53001,2 & 10 & \\
\hline \multicolumn{4}{|c|}{50880,24} \\
\hline 2020 & Forecast according to the linear trend model \\
\hline 2021 & \multicolumn{3}{|c|}{54256,77} \\
\hline 2022 & \multicolumn{3}{|c|}{57633,3} \\
\hline
\end{tabular}

Source: calculated by authors

Let's determine the forecast indicators of the volume of insurance payments and analyze a number of dynamics by extrapolation methods. The use of these methods is appropriate for small amounts of information. To determine the forecast indicators, the elements of the series are divided into two periods: according to the first period, conditionally called "prehistory", a model is built on the basis of which the forecast for the second period is made: 
Based on the data of the first six years (base year and the first 5 years), we calculate: the average absolute increase: $\bar{\Delta} Y=\frac{Y_{k}-Y_{0}}{k-1}=\frac{29736-23081.7}{6-1}=1330,86$ UAH. mln. shows that the average amount of insurance payments increases by this amount annually; the average annual growth rate: $\overline{\mathrm{K}_{\mathrm{p}}}=\sqrt[k-1]{\frac{Y_{\mathrm{k}}}{Y_{0}}}=\sqrt[6-1]{\frac{29736}{23081,7}}=1,05$ або $105 \%$ - shows that the amount of insurance payments increases by $5 \%$ annually.

Next, we make a forecast for the next period. The obtained calculations are compared with the actual data. The forecast indicators of the volume of insurance payments, determined by the average absolute growth and the average growth rate are given in table 4.

Table 4 Projected values of insurance payments

\begin{tabular}{|c|c|c|c|}
\hline \multirow{2}{*}{ Year } & \multirow{2}{*}{$\begin{array}{c}\text { Actual value, } \\
\text { UAH, mln. }\end{array}$} & $\begin{array}{c}\text { Py average absolute increase, } \\
\text { UAH, mln. }\end{array}$ & $\begin{array}{c}\text { by average growth rate, UAH, } \\
\text { mln. }\end{array}$ \\
\hline 2010 & 23081,7 & 28098,16 & 28105,67 \\
\hline 2011 & 22693,5 & 29429,02 & 29510,95 \\
\hline 2012 & 21508,2 & 30759,88 & 30986,50 \\
\hline 2013 & 28661,8 & 32090,74 & 32535,83 \\
\hline 2014 & 26767,3 & 33421,6 & 34162,62 \\
\hline
\end{tabular}

Source: calculated by authors

Based on the forecast, we calculate the long-term average annual growth rate based on the second period using the base year.

$$
\overline{K_{p}}=\sqrt[k-1]{\frac{Y_{k}}{Y_{0}}}=\sqrt[6-1]{\frac{53001,2}{26767,3}}=1,146 \text { or } 114,6 \% \text {, that is, in the }
$$

second period there is also an annual increase in revenues from insurance payments of $15 \%$.

The forecast of receipts of insurance payments in 20202022 will make:

$$
\begin{aligned}
& Y_{2020}=53001,2 \cdot 1,146=60739,38 \mathrm{UAH}, \mathrm{mln} . \\
& Y_{2021}=53001,2 \cdot(1,146)^{2}=69431,6 \mathrm{UAH} . \mathrm{mln} . \\
& Y_{2022}=53001,2 \cdot(1,146)^{3}=80031,8 \mathrm{UAH}, \mathrm{mln} .
\end{aligned}
$$

Thus, the forecast of insurance payments is based on trends that have developed in the "prehistory". However, it should be noted that these methods (average absolute growth and growth rate) have certain disadvantages. The main one is that these methods are based on the extreme levels of the series and do not take into account intermediate levels, which are sometimes decisive in determining the trend of changes in indicators. This is the reason for the decrease in the accuracy of the forecast and a significant discrepancy between the results obtained by the linear trend model and extrapolation methods. Also, given that the insurance market is developing in conditions of uncertainty and constant change, the possibility of applying traditional models based on the extrapolation of stationary processes is significantly limited.

Permanent changes in the external environment are most successfully taken into account in short- term forecasting, where the important dynamics of the studied indicator at the end of the observation period, rather than the trend of its development on average during the study period. Therefore, there is a need for such predictive models that would reflect the qualitative changes that occur in the patterns of development of the studied processes. The situation is exacerbated by the lack of a priori information about the nature of such changes. Given the above, we believe that the accuracy of forecast estimates can be ensured by adaptive models. Unlike other forecasting models, adaptive ones are able to take into account the evolution of dynamic characteristics when displaying the current state of the object under study [3].

Adaptive forecasting is developing in two directions: complicating the structure of forecasting models and improving adaptive mechanisms. At present, issues related to the problem of expanding the scope of application of the principles of adaptation to solving problems of long-term planning are becoming relevant. Adaptive models can be built using a small data set and are suitable for short-term forecasting, which is used in conditions of variability and instability of the environment.

Adaptive models and methods have in their structure a built-in mechanism that responds to changes in the studied indicator. Estimation of parameters of basic adaptive models is carried out on the first few observations; on its basis the forecast which is compared with actual data is made. In the next step, the model is adjusted according to the magnitude of the forecast error and then used to predict the next level; the procedure is repeated until all observations are exhausted.

Thus, the model at each step takes into account changes in the external and internal environment, adapts to changes and at the end of the period reflects the current trend. The forecast is the result of extrapolation of the latest trend [4].

We use a standard prediction algorithm by the method of double exponential Brown smoothing. Basic estimates of the model parameters are obtained by the method of least squares. To estimate the parameters in the Brown model, the prediction step $k=1$ and the smoothing parameter $\alpha=0,7$ were chosen. The optimal value of the discount parameter $\beta$ was determined using numerical optimization methods, provided that it is in the range from 0 to 1 . The results of the evaluation of the parameters of the Brown model are given in table 5 . 
Електронне наукове фахове видання з економічних наук "Modern Economics", №25 (2021), 52-57 https://modecon.mnau.edu.ua | ISSN 2521-6392

Table 5 The results of the evaluation of the parameters of the Brown model

\begin{tabular}{|c|c|c|c|c|c|}
\hline $\mathrm{t}$ & $y(t)$ & $a_{0}$ & $a_{1}$ & $\widehat{\boldsymbol{y}_{\mathrm{p}}}(\boldsymbol{t})$ & $\varepsilon(t)$ \\
\hline & & 13738,41 & 3376,53 & 17114,94 & \\
\hline 1 & 23081,7 & 20157,99 & 6419,58 & 26577,57 & 5966,76 \\
\hline 2 & 22693,5 & 27700,61 & 7542,62 & 35243,23 & 2202,03 \\
\hline 3 & 21508,2 & 34039,73 & 6339,12 & 40378,85 & $-2359,8$ \\
\hline 4 & 28661,8 & 41101,66 & 7061,93 & 48163,59 & 1417,27 \\
\hline 5 & 26767,3 & 46198,17 & 5096,51 & 51294,68 & $-3853,76$ \\
\hline 6 & 29736 & 49121,27 & 2923,1 & 52044,37 & $-4261,59$ \\
\hline 7 & 24844,2 & 45654,12 & $-3467,15$ & 42186,97 & $-12529,9$ \\
\hline 8 & 43431,8 & 43554,36 & $-2099,76$ & 41454,6 & 2681,15 \\
\hline 9 & 49367,5 & 44127,16 & 572,8 & 44699,96 & 5240,32 \\
\hline 10 & 53001,2 & 47503,68 & 3376,52 & 50880,2 & 5497,49 \\
\hline
\end{tabular}

Source: calculated by authors

Thus, for the last step we obtained an adaptive model of Brown, which has the form:

$$
y_{p}(n+k)=47503,68+3376,52 \cdot k
$$

To calculate the point forecast estimates for the following periods (2020-2022) in the above formula we substitute the value $k=1,2,3$ :

2020 p.: $y_{p}(11)=47503,68+3376,52 \cdot 1=50880,2$ UAH, $\mathrm{mln}$ 2021 p.: $y_{p}(12)=47503,68+3376,52 \cdot 2=54256,72 \mathrm{UAH}, \mathrm{mln}$ 2022 p.: $y_{p}(13)=47503,68+3376,52 \cdot 3=57633,24 \mathrm{UAH}, \mathrm{mln}$
Compliance of the model with the adequacy criteria determines its quality. Adequacy is characterized by compliance with statistical properties and the degree of proximity to actual data (accuracy). The model is considered adequate if the series of residues $(\boldsymbol{\varepsilon}(t))$ corresponds to the properties of randomness, independence of successive levels of the series and normality of the distribution [1]. The results of the study of the adequacy of the adaptive model for forecasting the volume of insurance payments are given in table 6.

Table 6 The results of the assessment of the adequacy of Browns model

\begin{tabular}{|c|c|c|c|c|c|c|}
\hline$T$ & $y(t)$ & $\varepsilon(t)$ & $\begin{array}{c}\text { Pivot } \\
\text { points }\end{array}$ & $\varepsilon(t)^{2}$ & $\varepsilon(t-1)$ & $(\varepsilon(t)-\varepsilon(t-1))^{2}$ \\
\hline 1 & 23081,7 & 5966,76 & - & 35602224,9 & - & - \\
\hline 2 & 22693,5 & 2202,03 & 1 & 4848936,121 & 5966,76 & 14173191,97 \\
\hline 3 & 21508,2 & $-2359,8$ & 0 & 5568656,04 & 2202,03 & 20810292,95 \\
\hline 4 & 28661,8 & 1417,27 & 1 & 2008654,253 & $-2359,8$ & 14266257,78 \\
\hline 5 & 26767,3 & $-3853,76$ & 0 & 14851466,14 & 1417,27 & 27783757,26 \\
\hline 6 & 29736 & $-4261,59$ & 0 & 18161149,33 & $-3853,76$ & 166325,3089 \\
\hline 7 & 24844,2 & $-12529,9$ & 1 & 156998895,2 & $-4261,59$ & 68365280,99 \\
\hline 8 & 43431,8 & 2681,15 & 0 & 7188565,323 & $-12529,9$ & 231376042,1 \\
\hline 9 & 49367,5 & 5240,32 & 1 & 27460953,7 & 2681,15 & 6549351,089 \\
\hline 10 & 53001,2 & 5497,49 & 1 & 30222396,3 & 5240,32 & 66136,4089 \\
\hline & $\Sigma$ & $-0,05$ & 5 & 302911897,3 & - & 383556635,9 \\
\hline
\end{tabular}

Source: calculated by authors

The randomness of the levels of a number of residues is checked on the basis of the criterion of turning points, according to which each level of the series is compared with two adjacent ones. Next, the sum of turning points is determined and its value is compared with the inequality:

$$
\mathrm{p}>\left[\frac{2 \cdot(\mathrm{N}-2)}{3}-1,96 \cdot \sqrt{\frac{16 \cdot \mathrm{N}-29}{90}}\right]
$$

According to our calculations, the sum of turning points is 5 , which is greater than 3 (calculations for inequality). Therefore, the above inequality holds, and a number of residues is considered to correspond to the property of chance.

The independence of the residues (absence of autocorrelation) is checked by the Darbin-Watson criterion, according to which the coefficient $d$ is determined. According to the calculations, the value $d^{\prime}=0,7(d<2)$, which indicates the absence of autocorrelation and independence of the residues.

The conformity of the residues to the normal distribution law is determined by the $\mathrm{R} / \mathrm{S}$ criterion, namely: 
$\mathrm{R} / \mathrm{S}=\frac{\varepsilon(\mathrm{t})_{\max }-\varepsilon(\mathrm{t})_{\min }}{\mathrm{S}}$ with critical levels that for $\mathrm{N}=10$ correspond to the interval $(2,75 ; 3,85)$. The value of $R / S$ calculated by us is equal to 3,28 and falls into the specified interval, which indicates the compliance of a number of residues with the normal distribution law and the admissibility of constructing confidence intervals for the forecast.
Thus, the calculations obtained by the adaptive model of Brown allow us to conclude about the adequacy of the model and its suitability for practical use in real economic conditions.

In order to determine the effectiveness of the forecasting methods used and to select the best forecast, the results of the calculations are summarized in a common table (Table 7).

Table 7 Estimated values of insurance payments are calculated using the methods used

\begin{tabular}{|c|c|c|c|}
\hline Years & $\begin{array}{c}\text { Linear trend } \\
\text { model }\end{array}$ & $\begin{array}{c}\text { Methods of extrapolation of } \\
\text { tendencies }\end{array}$ & $\begin{array}{c}\text { Brown's adaptive } \\
\text { model }\end{array}$ \\
\hline 2020 & 50880,24 & 60739,38 & 50880,2 \\
\hline 2021 & 54256,77 & 69431,6 & 54256,72 \\
\hline 2022 & 57633,3 & 80031,8 & 57633,3 \\
\hline
\end{tabular}

Source: calculated by authors

Thus, if we compare the three methods and the models built on them, it should be noted that only two of them most accurately reflect the real processes: a linear trend model and an adaptive Brown model. However, it is important to remember that the Brown model takes into account changes in the middle of the time series. In most cases, this model provides the most adequate forecast values, because the smoothing factors take into account the crisis periods that occur in the economy.

Conclusions. It was found that one of the barriers to the effective development of the insurance market in general and insurance companies in particular are the insufficient level of planning of their activities, especially in terms of forecasting key indicators. In the course of the research the optimality of planning is substantiated, it is shown that it can be achieved due to the accuracy of the forecast level of the planned indicators. In view of this, it was proposed to use modern forecasting methods depending on the purpose and forecasting period. The expediency of using adaptive methods is substantiated, because they are able to take into account the evolution of dynamic characteristics when reflecting the current state of the object under study under conditions of environmental variability. The effectiveness of Brown's adaptive model for short-term planning of insurance premium receipts is proved. The proposed model is tested for adequacy, based on its recommendations for further application in the practice of insurance companies.

\section{References:}

1. Abakumenko, O. V. (2013). Modeling the level of competition in the financial market of Ukraine. Business inform, 5 (2013), $302-310$ [in Ukrainian].

2. Official site of the National Commission for State Regulation of Financial Services Markets: Information on the state and development of the insurance market of Ukraine. Retrieved from http: https://www.nfp.gov.ua/en/Ohliad-strakhovoho-rynku.html [in Ukrainian].

3. Hurina, O. V. (2019). Adaptive models for forecasting the financial support of regional development. Modern Economics, 18 (2019), 31 35. DOI: https://doi.org/10.31521/modecon.V18(2019)-05 [in Ukrainian].

4. Kozmenko, O.V., Kozmenko, S.M, Vasilieva, T.A. etc. (2012). New vectors of development of the insurance market of Ukraine: monograph. Sumy: University Book [in Ukrainian].

5. Kozmenko, O.V. (2008). Insurance market of Ukraine in the context of sustainable development: monograph. Sumy: UABS NBU [in Ukrainian].

6. Official site of the State Statistics Service of Ukraine. Retrieved from http: http://www.ukrstat.gov.ua/ [in Ukrainian].

7. Statistics of the insurance market of Ukraine. National accounts of Ukraine. Retrieved from http: https://forinsurer.com/stat [in Ukrainian].

8. Guo Lijia (2001). Applying Data Mining Techniques in Property/Casualty Insurance. University of Central Florida. Retrieved from http: https://www.semanticscholar.org/paper/Applying-Data-Mining-Techniques-in-Property- -GuoA.S./a20fe61da7609f924970357632bb02ffb24e44fe [in English].

9. Yu-Ju Lin, Chin-Sheng Huang, Che-Chern Lin (2008). Determination of Insurance Policy Using Neural Networks and Simplified Models with Factor Analysis Technique. Wseas Transactions On Information Science\&Applications, 10, 5 (2008), 1415-1325 [in English].

10. Pukała Ryszard (2016). Use of neural networks in risk assessment and optimization of insurance cover in innovative enterprises. Economics and Management, 3, 8 (2016), 43-56 [in English]. 